\title{
CANNIBALISM, VEGETARIANISM, AND THE COMMUNITY OF SACRIFICE: REDISCOVERING EURIPIDES' CRETANS AND THE BEGINNINGS OF POLITICAL PHILOSOPHY
}

\author{
JOHAN TRALAU
}

$\mathrm{O}$ NLY SHARDS REMAIN OF Euripides' tragedy Cretans. Yet the fragments that we do have reveal a drama that is intriguingly packed with logical and argumentative peculiarities. Previous scholarship on this tragedy has, as we will see, been unable to account for these incongruencies. I will suggest a novel interpretation, namely, that Euripides elucidates a normative principle that is fundamental to his polity, and that the self-contradictions and tensions serve to present this principle in a curious yet systematic manner.

Moreover, I will argue that this discovery yields general insights about the role of logical thinking in Greek tragedy and in the early development of political thought. We will see that all these argumentative peculiarities have to do with food and sacrifice. My contention is that one needs to address these strange passages with an eye to the role of sacrifice, eating, and meat in the moral and religious universe of the Greek city - and that in light of a certain interpretation of sacrifice as a political institution, the strangenesses in Euripides' tragedy will appear remarkably reasonable. In making sense of a tragedy that seems to exclude any search for rationality and philosophical argument, I wish to make two contributions. First, given the interpretation suggested below, we will be able to understand a series of logical and argumentative improprieties that have haunted Euripides studies and, by extension, to understand Euripides, his political thought, and the polis itself in new and better ways. Second, I wish to show, in a very empirical way, that the view according to which Greek tragedy belongs to a "prelogical" cosmology — a road meandering through Nietzsche and Lévy-Bruhl to contemporary scholarship - is neither fecund nor true. What is at stake here is, then, no mere detail in Euripides, but the very adventure of rationality and interpretation pertaining to the classical world. The famously illogical Cretans would appear to be the least likely case of systematic political thought and normative

This article is part of the project The Origins of Political Philosophy in Ancient Greece, funded by the Bank of Sweden Tercentenary Foundation (dnr RFP12-0518:1). The author would like to thank CP's two anonymous referees for valuable critique and advice, as well as various audiences on Ramsö and in Sigtuna, Södertörn, and Uppsala, particularly Ludvig Beckman, Emanuel Karlsson, Patrik Klingborg, Kodama Satoshi, Mizutani Masahiko, Sofia Näsström, Sharon Rider, Hans Ruin, Claudia Lindén Ruin, Marianne Wifstrand Schiebe, Fredrik Sixtensson, and Anna Waern-Sperber. Most importantly, I owe a debt of gratitude to the members of the project, Dimitrios Iordanoglou, Otto Linderborg, Rosa Maria Lupo, and Charlotta Weigelt, who have made it an intellectual adventure of a very special (and rare) kind.

Classical Philology 112 (2017): 435-455

(C) 2017 by The University of Chicago. All rights reserved 0009-837X/17/11204-0002\$10.00 
principles. Yet out of what appear to be merely logical and argumentative errors, an astonishingly systematic complex of ideas will emerge.

The argument will unfold as follows. After briefly discussing the myth, the reconstructed drama, and some definitions, I begin the analysis by discussing argumentative peculiarities in the first choral song, pertinent to raw meat, vegetarianism, and cattle-herding. In the second step of the interpretation, I discuss another fragment, a debate that displays a puzzling analogy between cannibalism and omission of sacrifice. In the third part of the paper, I present an interpretation of Greek sacrifice, mainly deriving from the work of Marcel Detienne, that lets us discover sacrifice as a fundamental politico-theological institution; moreover, in accordance with the ethos of this institution all the argumentative improprieties actually make perfect sense. In the fourth part I discuss possible objections, and in the fifth part I suggest that my interpretation can account for what may be a different version of the myth. Finally, I argue that my interpretation should make us skeptical of the notion of Greek tragedy as being rooted in some sort of "pre-logical" cosmology; instead it should make us more sensitive to the possibility of reading Greek tragedy as a philosophical, argumentative, and rationalistic work of art.

First we will need to say something about the myth and the reconstructed drama. In the most common version of the myth, Europa is abducted by Zeus in the shape of a bull. The god brings her to Crete, and after Zeus' standard sexual transformation procedure she gives birth to Minos. Europa then marries the Cretan king, Asterios. Following the death of his stepfather Asterios, Minos and his brothers dispute the succession. Minos says that the gods have granted him kingship and that a magnificent bull will emerge from the sea to prove that this is the case. He then prays to Poseidon, who promptly sends a bull. Yet contrary to his promise to the god, Minos does not sacrifice the animal to Poseidon but keeps it. Infuriated, the god makes Minos' wife, Pasiphae, desire the beast. She makes the inventor Daidalos her accomplice and the latter builds a wooden cow. The queen slips into the cow, the bull arrives, and the two beget a monstrous child called Asterios, the Minotaur. ${ }^{1}$ Thus the myth.

In what is left of Euripides' play, a chorus of Cretan priests address Minos and present themselves, someone (possibly a nurse) informs someone else (possibly Minos) of the birth and nature of the Minotaur; later, Pasiphae and Minos argue about who is responsible for the monstrous birth, and Minos commands that she be locked up forever. At some - late - point in the play, Daidalos' son Ikaros sings a song. The play may have ended with a deus ex machina intervening, but we do not know. For our purposes, it is not necessary to solve the intricate questions about the structure of the drama and the attribution of verses to the different characters, for neither the authenticity nor the attribution of the pertinent passages has been questioned.

Before beginning, I will need to clarify a few key terms briefly. In the following, "principle" and "normative principle" will refer to a fundamental norm from which more specific rules, prescriptions, and prohibitions can be derived. I will speak of "inconsistencies" whenever a statement (for instance, a princi- 
ple) or action is logically incompatible with another statement or action, that is, in the case of a logical contradiction. I will use "incongruity" about a lower degree of argumentative impropriety. Tensions between phenomena in the text are, in this lexicon, for instance, cases of incongruity when a metaphor appears to be inappropriate in a certain context, or when two ideas are connected in the text that do not appear to be related, or when there is a transition between two ideas that appears to be too abrupt or inexplicable, that is, where we expect the ideas to be related but can find no such relation. Moreover, I will refer to both incongruities and inconsistencies as "argumentative aberrations," "improprieties," and "peculiarities." It could be objected that these standards of argumentation were possibly not acknowledged as such by, or even known to, the Greeks at this point. I will deal with this objection continually and attempt to show that it does not damage my argument.

What is of interest here is a chain of riddles that will be unravelled - and, in their own curious way, indeed solved - as we identify the normative principle that is at play in this tragedy.

\section{VEGETARIANISM AND RAW MEAT}

The chorus begins by addressing Minos (Cretans 472 Kannicht):

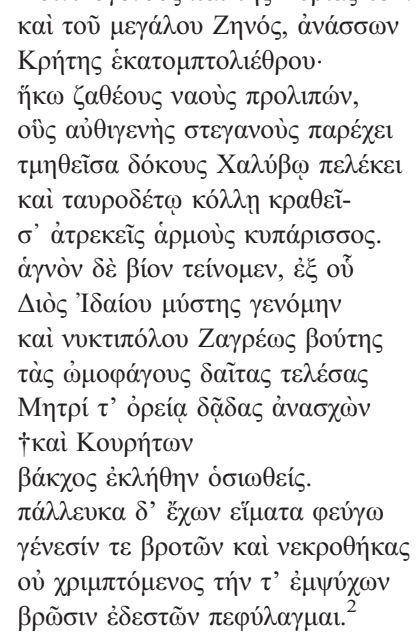

Son of Phenician-born Tyrian Europa and of great Zeus, you who rule over hundred-citied Crete, I have come here from a most divine temple, the roof of which is supplied by native cypress wood blended with bull-bound glue into precisely fitted beams cut with Chalybean axe. I lead a sacred life ever since I became an initiate of Zeus Idaios and the herdsman of night-wandering Zagreus, completing his raw-eating feasts and holding torches high for the Mother of the mountain, I was consecrated and named a celebrant of the Kouretes. I wear all-white clothing and avoid the generation of mortals, I do not go near burial-grounds, and I guard myself against the eating of living foods.

2. All fragments are from Kannicht's (2004) edition, reproduced here with the publisher's kind permission. All translations are mine. 


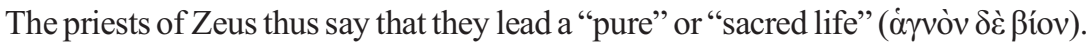
We note - though at this juncture only in passing - that they have left a temple

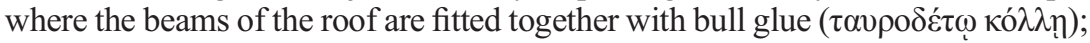
this could seem significant in a play about the genesis of the bull-man monster, the Minotaur. We will return to the glue shortly. But the most obvious way to understand $\dot{\alpha} \gamma v o ̀ v ~ \delta \grave{\varepsilon} \beta$ íov would be to identify it with the last four lines quoted. The priests wear "all-white clothing," they avoid either sexual intercourse or the places

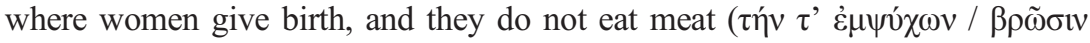
$\dot{\varepsilon} \delta \varepsilon \sigma \tau \tilde{\omega} v)$. This would all appear very pure in a certain perspective - that of vegetarianism, or perhaps more precisely, of the subversive vegetarians adhering to the supposed doctrine of Orpheus. ${ }^{3}$

At the same time, however, the members of the chorus say that they are the servitors of Zagreus, $\tau \grave{\alpha} \varsigma \grave{\omega} \mu$ feasts"). This is a bewildering line. Commentators have discussed to what extent this correlation between Zeus, Zagreus (and if the latter can in fact be equated to Dionysos, as is often supposed), and the mother of the mountain - Rhea - could make sense, or if it is some bizarre kind of syncretism. ${ }^{4}$ Martin P. Nilsson argued that they were a "mixture of all kinds of mystic cults," and that it is "hopeless, to try to discern what of it is Orphic." "While possible historical incompatibility between the cults is important for our understanding of the fragment, we will focus on another and potentially much more damaging tension. This tension has to do with raw meat. The priests' ritual consumption of raw flesh is, in the Greek context, disconcerting. Civilized people cook their meat; the uncivilized, and beasts, eat it raw. ${ }^{6}$

And then, the overwhelming question: How could these celebrations involving the eating of raw meat be consistent with the vegetarianism that the chorus claims to observe just a few lines later? One cannot be a vegetarian and eat raw flesh at the same time. This claim on the part of the chorus would appear to be an eruption of absurdity. Yet it is but the first instance in a series of seemingly irrational argumentative incongruities.

How can we make sense of this contradiction? In a recent edition, Christopher Collard and Martin Cropp argue that "[t]he apparent contradiction between flesh-eating and vegetarianism shows reality subordinated to the poetic." "Likewise, Robert Turcan suggests that the Euripidean inconsistency is due to "confusionnisme poétique." ${ }^{8}$ Poetic, then. But this claim would appear to create a new problem, while not solving the one that is already there. Why is the contradiction more poetic? And what would be the meaning of the inconsistency qua poetic?

\footnotetext{
3. Detienne $(2007,29)$ notes the Orphic animosity toward or lack of interest in women. In a fascinating and strangely compelling interpretation, however, Jesper Svenbro has argued that there is a connection between Orpheus and the fish ópøós, the hermaphrodite grouper, speculating about a very early phase in the myth in which Orpheus bemourns not a woman he once lost, but a woman he was - making Orpheus a myth of hermaphroditism; see Svenbro 2007, esp. 142-47.

4. Collard, Cropp, and Lee 1995, 67; Cozzoli 2001, 18-20; Jouan and van Looy 2001, 324; Cantarella 1963, 66; on the Zagreus issue, cf. esp. Gallistl 1981.

5. Nilsson 1935, esp. 222.

6. Cf. Thgn. frag. 541; Hom. Il. 22.347; Soph. frag. 799.5 Radt; Diog. Laert. 6.76; examples could be multiplied ad infinitum.

7. Collard and Cropp 2008, 539, ad loc.

8. Turcan 1986, esp. 245, cf. 236.
} 
Adele-Teresa Cozzoli, on the other hand, claims that the priests' feasting on raw meat and their vegetarianism are chronologically distinct, in the sense of different phases of the initiation in the cult- "queste celebrazioni sono ricordate dai coreuti come compiute non nel loro ruolo attuale di profeti del dio, bensì ancora in qualità d'iniziandi."' This would be a neat way of doing away with the inconsistency of eating raw meat and being a vegetarian: the celebrants begin with the former, then do the latter. The claim is not new. Wilamowitz made sense of the passage by saying that Euripides invented three different phases of initiation, yet added that they probably had no historical counterpart outside the poet's imagination, but were a strange conglomeration constructed for the purpose of ridiculing Orphic mysticism. ${ }^{10}$ Maurice Croiset made a similar claim about the conjunction being a Euripidean invention, and others have followed this track. ${ }^{11}$ Cozzoli differs from the earlier interpretations in claiming that Euripides did not make up this mixture, but alluded to a preexistent set of beliefs and practices that would not have struck the Greeks as incompatible or absurd. Cozzoli is thus innovative in collecting evidence purportedly corroborating the claim that omophagia was a rite de passage on the road to Orphic vegetarianism.

Unfortunately, there is no reason to suppose that this is what the chorus are saying. Cozzoli argues that such an abyss between initiands and the initiate would be quite normal in ritual contexts. But since the wording of the choral song does not unequivocally state such a distinction we would need some other kind of evidence that would make it plausible - possibly from contemporaneous or earlier cults prescribing eating of raw meat for initiands and subsequent vegetarianism for the initiate. In another commentary, however, Collard, Cropp, and Lee have already argued that this conjunction of the two phenomena is inconsistent, that they are "brought together artificially, and are nowhere attested for any one cult or sect." ${ }^{.12}$ And the counterevidence adduced by Cozzoli is not convincing. She points out that Plutarch mentions ritual feasting on raw flesh as well as fasting. But Plutarch says nothing about any cult that would prescribe principled vegetarianism as well as omophagia - and fasting followed by feasting would appear to be standard religious procedure and quite distinct from the problem at hand. ${ }^{13}$ Moreover, Cozzoli cites Diogenes Laertios' observations (7.13) about the Pythagoreans abstaining from eating meat; yet this does not prove anything about any supposed conjunction of vegetarianism and raw meat-eating.

More recently, however, Ana Isabel Jiménez San Cristóbal has argued - tentatively so - that there may have been an Orphic initiation ritual that included sacrifice. On the basis of two texts, the Cretans and a damaged Hellenistic papyrus from Gurob, Jiménez makes the claim that the devouring of meat could have been part of the initiation. As a single document by an arguably eccentric poet, the Cretans is slender evidence, particularly since a number of Euripides scholars have suggested that the description serves to stultify the cult. ${ }^{14}$ Most

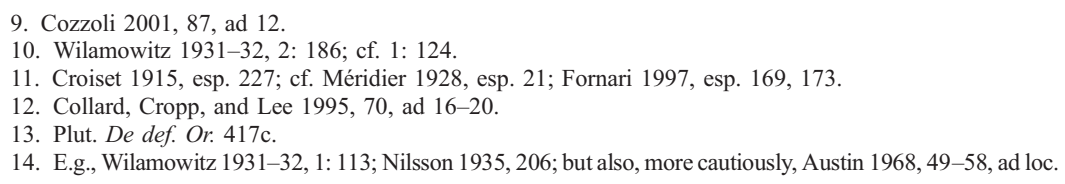


importantly, the argument can obviously not be used in the context of the Cretans fragment without being self-defeatingly circular. Moreover, the problem with the papyrus is that, according to Jiménez' own interpretation, it mentions fire and hence cooked sacrificial meat. In short, there is no trace of omophagia in the latter text, so it is questionable if it can in fact be used to buttress the view that Orphism implied vegetarianism as well as ritual eating of raw meat. ${ }^{15}$ The single instance of supposed omophagia is to be found in Euripides, and it remains, precisely, single. We must concur with an historian of Orphism, then, who says that Euripides' bringing together of omophagia and vegetarianism mingles "hardly compatible ritual elements." 16

Other recent commentators, such as François Jouan and Herman van Looy, have passed the issue of inconsistency in silence, discussing the compatibility between Zeus cult and Dionysian rites yet avoiding the logical problem of vegetarianism versus omophagia. ${ }^{17}$

We are left, then, with an enigma. Euripides has handed a logical inconsistency to us, and earlier scholars have not managed to solve it. It could be objected that the conception of a logical inconsistency had not been developed or discovered at this point. ${ }^{18}$ It is true that the discovery of the distinction between different kinds of necessities - physical, moral, logical — was a gradual accomplishment. If we follow G. E. R. Lloyd, however, "beginning with Parmenides, perhaps, these terms [pertaining to necessity] acquire a new use in the context of logic."19 Even if we opt for a very early dating of the Cretans, say, in the 450s, the drama must be later than Parmenides. ${ }^{20}$ Someone could again object that, Parmenides or not, the cosmology of Greek tragedy was not yet familiar with the idea that a self-contradictory statement must be wrong. ${ }^{21}$ But this is not true, for the mother of all normative arguments in tragedy, Aischylos' Oresteia, conspicuously employs such claims with astonishing precision, demonstrating inconsistency in different arguments with regard to the compatibility of principles and other normative claims, as well as the concomitant insight that an inconsistent argument cannot be valid. ${ }^{22}$ In short, the conception of logical necessities and inconsistencies was no stranger to the universe inhabited by Euripides, tragedy, and the city, and it is more than likely that the conjunction of vegetarianism and omophagia must be - and must have been - understood as inconsistent.

Moreover, when we look more closely at this choral song we will see that the self-contradiction does not seem to have been created at a whim. At the very least, in this brief passage the use of argumentative improprieties seems to be

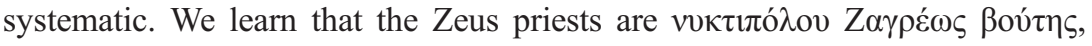

\footnotetext{
15. Jiménez San Cristóbal 2009; she adds the argument (p. 93) that according to the myth Dionysos was only half-cooked-"rare" - when he was eaten by the Titans, a fact that is supposed to mediate between the omophagia in Euripides and the traditionally cooked and sacrificed meat in the Gurob papyrus. This would, however, seem to make the question of omophagia, vegetarianism, and sacrifice even more confusing.

16. Herrero de Jáuregui 2010, 28 n. 59; cf. likewise Festugière 1972, esp. 39-40.

17. Jouan and van Looy 2001, 314-15.

18. As argued by Oudemans and Lardinois $(1987,206)$

19. Lloyd 1966, 422.

20. Cozzoli (2001, 9-11) argues for the period between 442 and 432.

21. In the vein of, e.g., Oudemans and Lardinois $(1987,206)$.

22. Cf., e.g., Aesch. Eum. 642, where the Erinyes reject Apollo's argument about Zeus and filial piety: $\pi \tilde{\omega} \varsigma$

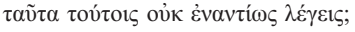


"herdsman of night-wandering Zagreus." For sure, this is a metaphor: Zagreus, be he Dionysus or someone else, does not possess cattle that his followers tend to. ${ }^{23}$ Yet even as a metaphor, it is in tension with Orphic vegetarianism-vegetarians do not, in general, keep cattle. On the contrary, cattle-herding typically involves slaughter and meat-eating, regardless of whether animals are kept primarily for the purpose of producing work animals, hides, and wool, or for the production of meat or milk. ${ }^{24}$ On the contrary, cattle-herding involves slaughter and meat-eating. This is, of course, not a logical inconsistency if we understand the wording metaphorically, that is, as non-literal and somehow improper in the first place. But if a good metaphor is, as argued by Aristotle, always constructed from two phenomena that are related in a way that is made visible by the metaphor, then the idea of the Orphic vegetarian as a cattle-herder would appear strange, possibly too strange. ${ }^{25}$

This tension between the image of the priests as cattle-herders and their selfprofessed vegetarianism would be alleviated if we would choose to follow Coz-

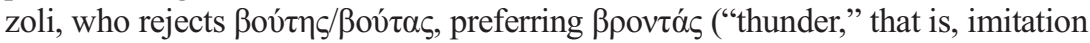
of thunder by means of drums as part of a ritual) - a minority position, but still possible. ${ }^{26}$ Yet there is more: the kind of tension that we have detected seems to be systematic.

The temple that the chorus speaks of is itself the embodiment, so to speak, of the killing and sacrificing of animals. It is built $\tau \alpha \nu \rho o \delta \varepsilon ́ \tau \omega$ кó $\lambda \lambda \eta$, with "bullbound glue." Walter Burkert says that Euripides" "dichterische Phantasie" has come up with a "mit Stierblut versiegeltes" temple, that is, that bull blood has been sprinkled on the building as part of a ritual. ${ }^{27}$ But this is an unnecessary conjecture; it is much more reasonable to suppose - as do most commentators - that the cypress beams are considered to be fitted with bull glue. ${ }^{28}$ There is nothing strange about bull glue in itself. ${ }^{29}$ Pliny tells us that glue made of bulls' ears and genitals is the best. ${ }^{30}$ And Otto Kern argued that Orphic sanctuaries were built in conjunction with cypress groves. ${ }^{31}$ Moreover, the cypress was connected with Crete in the Greek imaginary. ${ }^{32}$ Furthermore, the cypress tree evokes death and mourning. 33

But what is truly remarkable is that the temple itself presupposes the death of animals - in the Greek context, sacrificing the bull, cutting it, offering parts of it to the gods, eating the meat and, as a byproduct, boiling the skin, the genitals, or the ears in order to produce glue. Again, this is not inconsistent in the sense that two propositions are logically incompatible, but the Orphic vegetarianism of the

\footnotetext{
23. Jouan and van Looy $(2001,311$, ad loc.) point out that Euripides at the very least "évite l'identification explicite" of Dionysus and Zagreus.

24. Cf. Jameson 1988, esp. 88, 96; Rosivach 1994, 84, 144

25. Arist. Rh. $1412 \mathrm{a} 10-11$.

26. Cozzoli 2001, 86, ad loc.

27. Burkert 1977, 419; cf. Harrison 1903, 482.

28. Cozzoli 2001, 82-83, ad loc.; Collard, Cropp, and Lee 1995, 68, ad loc.

29. Hodge 1960, 97, 126; Burford 1969, 183.

30. Plin. HN 28.71, 11.231; cf. Arist. Hist. an. 517b28-29, cf. 523a15-17.

31. Kern 1916, esp. 561 .

32. Diod. Sic. 5.66.1; Pl. Leg. 625b; Käppel 1992, 123-25, on Pind. Pae. 4.50-51.

33. Hünemörder 2003, 870; Verg. Aen. 3.64; Thuc. 2.34.3; Ov. Met. 10.136-42.
} 
chorus would appear to be incongruent_- "sit uneasily"-with their temple being the product of slaughter and the boiling of bovine carcasses.

In short, Euripides has evidently constructed a not-so-neat inconsistency. On the one hand, there is vegetarianism; on the other hand, there is the herding of cattle and the use of dead animals' bodies for architectural and ritual purposes; on the - impossible, monstrous - third hand, there is the disconcerting and uncivilized eating of raw meat. Earlier scholars have not solved this riddle.

\section{SACRIFICE AND CANNIBALISM}

Baffled yet undaunted, we move on to the other larger fragment, containing the debate between Pasiphae and Minos (472e9-10).

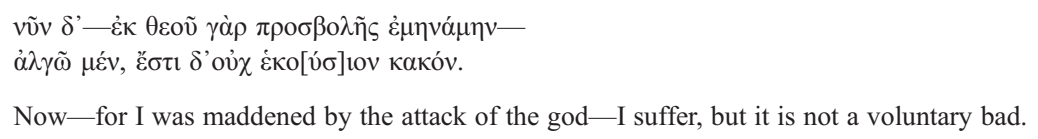

In fact, Pasiphae says, someone else is responsible (472e23-24):

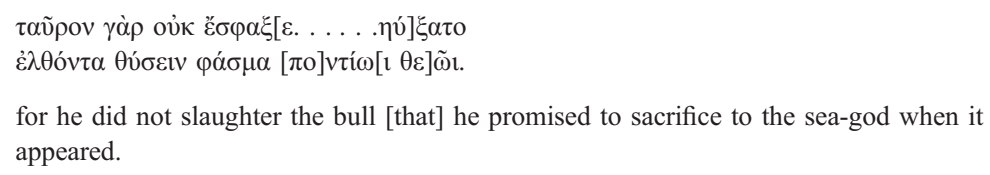

The latter words may, as David Sansone has recently argued, be addressed to a deity, not to Minos - as an intermezzo, with Minos present. ${ }^{34}$ In any case, Pasiphae argues that she is not responsible for the monstrous birth and the preceding monstrosities. ${ }^{35}$ She acted at the instigation of the god, the ultimate reason being the fact that Minos had not sacrificed the bull to Poseidon. What she

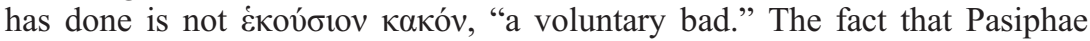
evokes the notion of voluntariness is, in its own way, interesting. For the Greek legal systems and morality of the epoch, the question of responsibility for the consequences of one's actions was a problem - indeed, in Euripides' time, the orator Antiphon discussed cases pertaining to involuntary harm from opposing views. ${ }^{36}$ Archaic societies had in general held the view that people are responsible for the consequences of their actions regardless of whether the effects were in fact intended or foreseeable, but already early there are indications, for instance in Solon, that Greek thinkers conceived of this as unjust, and perhaps even thought that people are in fact only responsible for consequences that they intend or should be able to predict. ${ }^{37}$ The role of the intention in Greek morality is in any case contested - in the sense that this was the case in Greek societies, but also in contemporary scholarship. ${ }^{38}$ And if one adheres to the view that intention or neglect of foreseeable risk is more or less a prerequisite for responsibility, it would seem that Minos rather than Pasiphae is in fact responsible

34. Sansone 2013.

35. Margot Schmidt has argued that at this point the Minotaur is locked up in the labyrinth; see Schmidt 1992, esp. 309

36. Antiph. 3.1.2, 3.4.8 Decleva Caizzi.

37. E.g., Solon 13.31-32 West; cf. Snell 2000, 27-29.

38. Contrast MacLeod 2001, 83, 88-89, with, e.g., Pippin Burnett 1998, 138, and Giuliani 1998, esp. 31. 
for the prodigious birth of the Minotaur, since he is the one who wilfully neglected the promise of sacrifice, thus causing the wrath of the god and the monstrous desire of Pasiphae. ${ }^{39}$ And this is what she says (472e 34-35):

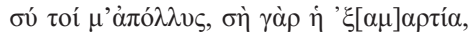

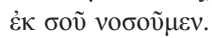

You ruined me, yours was the error, because of you I ail.

Pasiphae's defense is, says one writer, a "beautiful piece of rhetoric."40 "[S]ophistic brilliance," another scholar claims. ${ }^{41}$ Yet another speaks of the "rigorosa tecnica" of the argument. ${ }^{42}$ Already Wilamowitz argued that the speech exhibits “die Kraft seiner [Euripides'] sophistischen Dialektik auf seiner Höhe.",43 The issue of responsibility and guilt in the Cretans is interesting in its own right. ${ }^{44}$ But what is bewildering about the fragment is what comes afterward (472e 35-39):

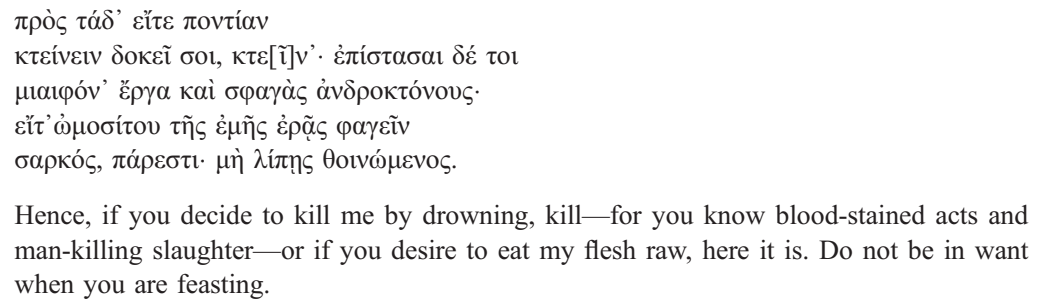

Pasiphae taunts her husband, asking him to kill her. The first possible punishment calls for no lengthy explanation. Drowning her in the sea would, in its own way, appear congruent with her crime: the calamitous bull came from the sea, and drowning her could seem to expel the pollution, bringing it back where it came from (a similar consideration is to be found in Euripides' Helen). ${ }^{45}$ The other possibility does, however, prima facie sound absurd. Why does Pasiphae say that Minos is well acquainted with the foul killing of men? Moreover, why does she depict him as a would-be cannibal, sarcastically offering him her flesh? Where, then, does the topic of cannibalism come from?

The transition to cannibalism is enigmatic. Moreover, if, as argued by previous commentators, Euripides reflects state-of-the-art legal argumentation ${ }^{46}$-if, indeed, this is "beautiful [. . .] rhetoric" "brilliance" 48 - then Pasiphae's words would appear to be not only abrupt but inexplicable.

Why cannibalism? This is, strictly speaking (and unlike the words about indulging in omophagia and vegetarianism in the first choral song), not a logical

39. Cf. Dolfi 1984

40. Webster 1967, 90.

41. Reckford 1974, esp. 319

42. Cantarella 1963,78 .

43. Wilamowitz 1907, 73-79, esp. 79

44. Cf. esp. Dolfi 1984.

45. Eur. Hel. 1271; cf., by the way, Porph. Abst. 1.42 .3

46. Jouan and van Looy 2001, 313; Collard, Cropp, and Lee 1995, 73; Collard and Cropp 2008, 532

47. Webster $1967,90$.

48. Reckford 1974, 319 
inconsistency. But the utterance appears to be incongruent with what precedes it, and such incompatibility, such an apparent interruption of the sequence of ideas, needs to be accounted for. Since most of the play is lost, we do not know if it alludes to some theme that had already been addressed in the drama. Wilamowitz claimed that this must have been the case, yet conceded that the tragedy itself offered no such clues. ${ }^{49}$ Croiset argued that the perplexing utterance must have something to do with previous "actes de barbarie" perpetrated by Minos. ${ }^{50}$ But this is not plausible, for we have no indications of such deeds on his part at this juncture in the myth (later, of course, Minos will demand that Athens send young men and women to be killed by the Minotaur, but in the internal chronology of myth, this is all still far away). And no other available mythographic or other evidence could make good sense of Pasiphae's words either. Cozzoli, who is always eager to iron out any logical or argumentative problems in the Cretans, says that it is an "esplosione d'irrazionalità," yet adds the psychologizing explanation that in the heat of the argument, Pasiphae has cannibalism represent hatred of other people. ${ }^{51}$ Another critic says that Pasiphae's words express "sarcasm." 52 But the question is why the accusation about cannibalism would be appropriate as sarcasm, that is, what it could possibly connect with in the mythological universe of Minos.

It could be objected that the Greeks may have been less susceptible to such abrupt transitions or ruptures in a sequence of arguments. We need to be sensitive to that possibility. But the question is if we can find other parallel cases in Greek sources engaging in normative argument. One possibility would be the debate with Kallikles in Plato's Gorgias, where Socrates suddenly seems to change the topic, from ruling over other people to ruling over one's self, that is, the dignity of controlling one's urges and desires. ${ }^{53}$ This has been considered an abrupt shift, perhaps even as an act of manipulation on Socrates' part. ${ }^{54}$ Yet in the Platonic context, perhaps even in that of Greek political ethics in general (or so Socrates seems to want us to think), the connection was possibly considered natural and straightforward: the tyrannical desire to control other people was conceived of as akin to lack of self-control. So what appears to be a rupture in the text would in fact, as it were, be telling: it lets us discover the greater idea behind the dialogue. We may thus arguably expect such a correlation in the Cretans as well. Moreover, it could be noted that earlier scholars have felt the need to account for the abrupt nature of the passage, whether (with Wilamowitz and Croiset) by referring to a lost chain of thought, or (with Cozzoli) by understanding it as an argumentative peculiarity which is due to Pasiphae's emotions. Common to these previous interpretations is hence the assumption that the seemingly over-rash transition must be explained in terms of a correlation with some other ideas in the thought complex of the Cretans. I will argue that one can account for this rupture in the sequence of arguments in a different, and better, way.

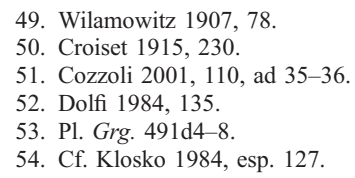


The first thing to note, at this time, is that cannibalism is a disconcerting theme, and that it should be understood through the lens of sacrifice. Pasiphae's

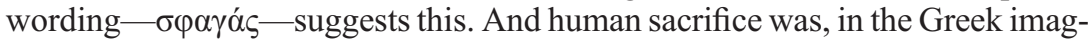
inary as well as in many other places, often thought of as being connected with cannibalism and vice versa. In Plato and others we find references to the ritual killing, cooking, and eating of children in Arcadia, in the context of the myth of Lykaon-sometimes, intriguingly, the philosopher speaks of it as a contemporary institution, while in other places he seems to be hesitant about the actual existence of this man-eating ritual. ${ }^{55}$ Some scholars argue that there may in fact have been some truth in the account of actually existing human sacrifice and concomitant cannibalism in Arcadia. ${ }^{56}$ In any case, let us note that cannibalism evokes sacrifice, and that in Pasiphae's speech, the idea that she conjures up must be considered to be troubling.

We have thus far found one logical inconsistency regarding vegetarianism and omophagia, two argumentative incongruencies pertaining to the herding and killing of cattle as well as the use of carcasses for architectural purposes, and one remarkable incongruency regarding cannibalism. We note that these problems - the Orphics and their consumption of steak tartare, the sacrifice omitted by Minos, the instrumentalization of animals, and the riddling accusation regarding cannibalism - are all to do with food, eating, and sacrifice. How do we make sense of these argumentative peculiarities? One answer could be that we should not. We could say that the monstrous desire underlying the drama is an "anomalie [. . . impropre à toute généralisation," and that we should understand the logical perversions of this tragedy in the same way, just leaving them as they are. ${ }^{57}$ And looking at some standard toolboxes in the humanities, this may be the answer we come up with: insisting on the consistency of the text will, or so some scholars argue, be conducive to "mythology of coherence," 58 imputing ideas to the text that do not belong there. If we follow the implications of this fear of supplying logical consistency where in fact there is none, then we should maybe just note the inconsistency - or perhaps not even evaluate it as an inconsistency - and move on. I will instead suggest a very different solution.

\section{THE FLESH OF THE CITY}

The eating of raw meat, vegetarianism, and cannibalism: they all appear to be intimately related in Euripides' drama. But thus far this has appeared to be quite a nest of contradictions and incongruencies. To solve this riddle we will need to approach the principles regulating the devouring of flesh not in Minoan Crete, but in Euripides' city.

In ancient Greece, meat was not everyday nourishment. The Athenians, who were blessed with more meat than most other Greeks, received almost all of it from sacrifice, and their diet consisted mainly of plant and dairy products. ${ }^{59}$

55. Pl. Resp. $565 \mathrm{~d} ;$ Leg. $782 \mathrm{c}$.

56. Bremmer 2008, esp. 76-78.

57. Rivier 1960, esp. 57.

58. Skinner 2002, esp. 67.

59. Jameson 1988, esp. 87, 105; Rosivach 1994, 2, 85, 158; cf. Heath 2005, 2. 
Yet the killing and eating of animals is fundamental to the order of the polis and of the world. Through the sacrifice of animals, the cosmological hierarchy of god, man, and animal is maintained. The animal, which is ontologically subordinate to man, is slaughtered; human beings eat the meat; the gods above are offered other parts of the body and receive the scent. Sacrifice thus secures the position of man downward and upward, between beasts and gods. ${ }^{60}$ Specifically, human beings are different from the god and the animals in roasting or boiling meat. Animals eat raw flesh, gods eat ambrosia.

And this makes grilling the foundation of civilization itself. The order of the universe and the political community is dependent on the human institution of killing animals, cooking the meat, and eating it. Civilized people cook meat; uncivilized people eat it raw. Food and sacrifice are thus intimately related. In the words of Marcel Detienne, "pour toute la pensée grecque, la nourriture humaine est inséparable du feu sacrificiel.," ${ }^{, 61}$ Once we see this, we discover the fundamental principle of the polis.

Moreover, because of this unity of sacrifice and cooked meat as the everrenewed beginnings of civilization, deviations from the principle are distortions of the cosmic, theological, and political order. In Euripides' time, this principle was not uncontested. On the one hand, adherents of the Orphic life, as well as Pythagoreans, denounced the eating of meat. On the other hand, the Dionysiac cult was associated with celebrants' tearing the limbs off from the bodies of animals and even people, and eating raw flesh. ${ }^{62}$ Both sides refuse to take part in the human institution that, according to the principle of sacrifice, maintains the order of gods, human beings, and animals.

This has a number of intriguing implications. First, abstaining from the ritual and from meat will, as Detienne says, be an "acte hautement subversif" to the polis. ${ }^{63}$ Those who refrain from participating in sacrifice place themselves "en dehors du monde de la cité": they not only believe something else, but are outside of the cycle of festivals that structure the year and the political community. ${ }^{64}$ They do not take part in some of the fundamental political institutions of the city. Second, and most importantly, Detienne has argued that these different revolts against the city, "Orphism" and the Dionysiac cult, are symmetrical in their refusal of the normative principle underlying the conception of social and cosmological order. Orphic vegetarianism and Dionysian omophagia are, then, complementary in being two different ways of opposing the principle of sacrifice and roasted meat. ${ }^{65}$

Omitting sacrifice and the eating of meat is consequently considered to be related to other fundamental perversions of order. Indeed, a philosopher whom we cannot accuse of merely reproducing the moral prejudices of his polity treats cannibalism as part of the same complex as parricide and incest. ${ }^{66}$ And in a dif-

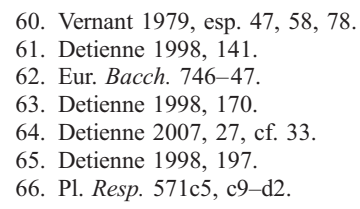


ferent way, of course, cannibalism too is a radical protest against the order of the polis and the world, for it refuses to acknowledge the traditional distinction between human beings and animals. Hesiod formulates the difference when saying that Zeus has given human beings Dike, Justice, and that they may for this reason - and unlike animals - not devour one another. ${ }^{67}$ Cannibalism is, then, likewise a revolt against the very source of civilization.

The fundamental normative principle is thus that it is imperative for humans to sacrifice animals to the gods, cook them, and eat them. By taking part in this political institution, human beings maintain their position, different from animals, and they exhibit appropriate reverence to the gods. By properly slaughtering animals we uphold the cosmological hierarchy and order, and that makes sacrifice and meat-eating a politico-theological obligation. As pointed out by Jean-Louis Durand, the city is thus a community of people sacrificing together, prohibited to spill each other's blood, and united by virtue of the complex system of prescriptions and prohibitions relating to the ritual slitting of the throats of animals. ${ }^{68}$ While this is arguably in one sense a universalistic principle pertaining to the position of human beings in the world, it understands humans as members of particular sacrificial communities.

What is the implication of all this? In light of the principle that we have excavated, vegetarianism, omophagia, and cannibalism are similar and symmetrical in their subversion of the cosmological and public order. In Euripides, we found a bewildering conjunction of omophagia and vegetarianism, both of which the chorus claims to have observed, of vegetarianism and the use of animals, as well as a startlingly abrupt transition into the issue of cannibalism. Yet after having rediscovered the principle underlying sacrifice, meat-eating, and the order of the world, we should no longer find it startling. Again, the literature on Euripides and the Cretans has not been able to account for the strangenesses in the argument. Yet in light of the interpretation of Greek sacrifice deriving from Detienne and others and outlined above, the strange incongruencies actually make sense.

The strange coexistence between the chorus' omophagia and vegetarianism is, of course, not possible. Yet judging by the principle of sacrifice, omophagia and vegetarianism are analogous distortions of order - the order that is maintained by the roasting of meat in honor of the gods and for the benefit of human beings. In this respect, Orphic vegetarianism and Dionysian feasting on raw meat are similar. They are both contrary to the principle of the polis. It is possible, then, indeed most probable, that Euripides elucidates this fundamental principle by constructing an inconsistency, and hence showing that vegetarianism and omophagia are aberrations from the perspective of the principle.

Likewise, the principle will help us make sense of Pasiphae's curious evocation of cannibalism. Against the backdrop of the interpretation of Greek sacrifice, the sudden reference to the devouring of human flesh is an ingenious way of exploring the implications of that principle. For if sacrifice is necessary as a means of maintaining order in the world and in the city, then all omissions are, in one respect, similar perversions. We know that Minos did not perform

67. Hes. Op. 276-80.

68. Durand 1997, esp. 42. 
the sacrifice - in that sense, and in light of the normative principle, his omissions and actions are akin to cannibalism.

This is not to say that Euripides, or any Greek legal system, actually considered vegetarianism and cannibalism to be morally equivalent. But what I argue is that according to the principle of cosmological and political order embodied in roasted meat, these modes of eating - cannibalism, vegetarianism, and omophagia - are similar in not respecting the principle. Refraining from "living food"

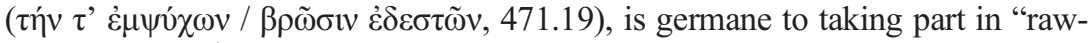

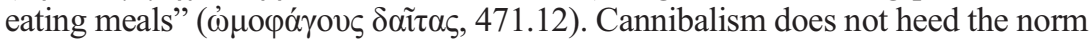
that people eat animals, not people; vegetarianism refrains from flesh; omophagia omits the proper treatment of meat, that is, cooking it. As such, these practices deviate from the order of the polis. ${ }^{69}$ What Euripides does, then, is to unveil the implications of the normative principle of the sacrificial community and the order of the world.

\section{ANIMALS, HuMANS, AND OTHER HYPOTHESES}

Two objections could be made to the thesis developed in this article, and we will need to deal with them before proceeding to the implications of the interpretation. First, it could be argued that the interpretation undertaken here is not surprising, or not surprising enough, given the conception of Greek sacrifice outlined above. If we accept the understanding of the sacrificial community spearheaded by Detienne, then it makes perfect sense for an Athenian dramatist to bring together omophagia, vegetarianism, and cannibalism as subversive deviations - meaning, or so someone could argue, that the interpretation is self-evident and possibly superfluous. Yet while it is perfectly compatible with the conception of Greek sacrifice discovered by Detienne and others, it should be noted that this kind of interpretation has never been undertaken by Detienne or any other scholar - neither of the Cretans nor of the sort of argumentative strangeness explored above - and that earlier scholars have been unable to solve these riddles pertaining to Euripides, tragedy, and the development of normative argument.

Second, however, it could be objected that the interpretation developed here is too surprising, in the sense that the conception of sacrifice underlying the argument is wrong, or too controversial to make for a plausible interpretation. In this vein, one could claim that the sharp line between animals and men is made much too sharp by Detienne, Vernant, Durand, and others, that those borders were often porous and sometimes blurred in the Greek world. It is true that there were undeniably Hellenic ideas about the relation between humans and animals that seem to diverge wildly from the strict distinction discussed above. The most radical of these would be the conception of a kind of fundamental affinity between a human being and an animal - more often than not a hunter or a warrior on the one hand, and a great animal, typically a predator, on

69. It could be objected that this argument trades on a hypostatization of "Orphism" (cf. Edmonds 2008). But my argument is that if, as argued by Detienne, vegetarianism, omophagia, and cannibalism are similar-regardless of ascriptions or subscriptions to -isms - in the perspective of the principle, then Euripides' argumentative aberrations are no longer inexplicable. 
the other hand. It was often thought that a hunter would acquire the qualities of the prey. Apollodoros tells us that Argos, a creature with unmistakably bovine

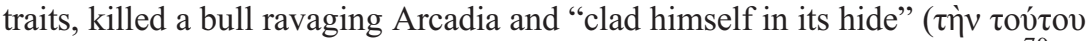

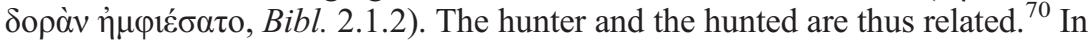
the words of Walter Burkert, "Der Besieger des Stiers wird, mit der Haut des Opfers umhüllt, gleichsam selbst zum Stier." ${ }^{\text {,1 }}$ The same idea about affinity between humans and dangerous animals can be traced in a great number of Greek literary sources and myths, as well as in the visual arts-lion-like Herakles and the lion are but one example. ${ }^{72}$ Moreover, myths and rituals pertaining to this community between a human being and a wild animal-leopards, bears, wolves - can be found in many other cultures; sophisticated reflections of it are, for instance, undertaken in Sophokles' Trachiniai and Arnold Schwarzenegger's Predator. ${ }^{73}$ This is evidently very different from the stark contrast between man and animal, and it is a thought complex that is sometimes unduly downplayed by scholars making productive arguments about the strong Greek distinction between humans and beasts. ${ }^{74}$

Furthermore, the difference between the notion of the affinity between man and animal and the strong distinction between men and beasts does not seem to coincide completely with the difference between hunting and war on the one hand and sacrifice on the other. Not only were domesticated animals sacrificed, but wild animals as well, including tuna and eel. ${ }^{75}$ Finally, it could be argued that the socalled Unschuldskomödie, the perceived need to make the animal "consent" to the sacrifice by inducing it to "nod" when drinking from a water vessel, suggests that the Greeks perceived some sort of affinity with the animal. ${ }^{76}$

These are important objections, and dealing with the full complexities of the argument and the sources would require a book of its own, or possibly a library. The world of Hellenic animals is complex-Detienne and Svenbro themselves astutely highlight the role of the wolf as a cook in Greek thinking, whose breath "cooks" the meat of the prey, and as a social animal incapable of justice, and hence as a beast that does not fit nicely with the strict distinction. ${ }^{77}$ But one way of defending my argument cautiously would be to say that it relies on one way of understanding the Greek view of men and animals, that it expresses one Greek idea that appears to be prominent in many myths and institutions, and that as a working hypothesis in this context, its value resides in its potential to account for questions that will otherwise remain enigmatic. And surely, if we accept the interpretation suggested here, then Euripides' argumentative aberrations are no longer riddling.

Moreover, it would seem hard to deny that the distinction between humans and animals is of utmost importance in many dimensions of Greek society. As pointed out by Vernant, Hesiod insistently emphasizes the difference between

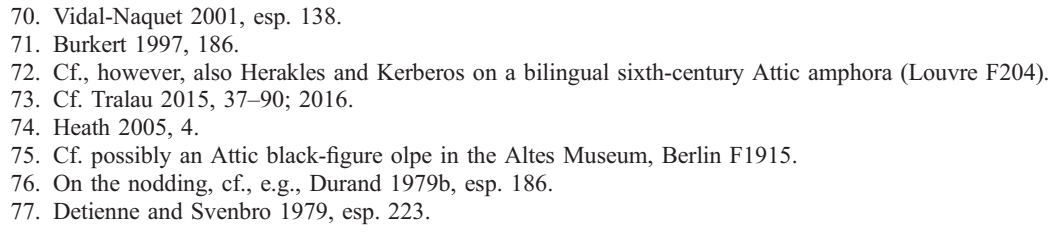


gods, men, and animals - and this is surely the standard Hellenic etiological account of sacrifice. ${ }^{78}$ It could be objected that it may have been possible to be a vegetarian in the city without attracting hostility. But sacrifice was evidently a normatively charged issue. Plutarch tells us that Solon prohibited "private" bull sacrifices in the context of funerary ritual, meaning that sacrificing such an important animal had to be a public affair. ${ }^{79}$ Empedokles is reported to have sacrificed a false ox made of honey and flour, but we do not know how controversial this was. ${ }^{80}$ If we imagine the possibility of taking part in the celebration of public sacrifice while refusing to eat meat, however, we may recall the fact that the very concept of "sacrifice" lacks an appropriate Greek equivalent that would allow for a distinction between eating and sacrificing in the sense of killing. As argued by Durand, $\theta v \sigma i ́ \alpha$ connotes slaughter, religion, cooking, and eating, all at the same time ${ }^{81}$ And the moral scandal involved in not eating the sacrificed meat is arguably still felt in Porphyrios, centuries after Euripides. In a saying reported by the Platonic and vegetarian philosopher, we learn that normal and vulgar people, "the man on the street" in the city, say "that it is in accordance with nature for man to

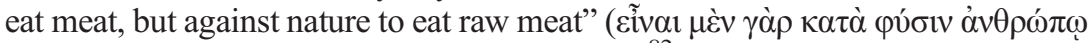

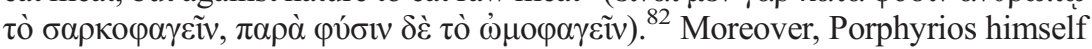
expresses great dislike of those people who claim that vegetarianism ( $\tau \dot{\eta} v \dot{\alpha} \pi \mathrm{x} 0 \chi \dot{\eta} v$

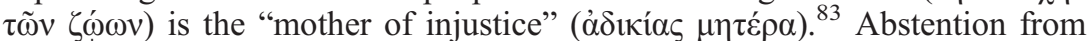
meat is thus, according to the morality that is still alive in Porphyrios' time, not only bad in itself, but the fountainhead of a number of other vices - once again, then, the political, moral, and theological conception that we unearthed in Euripides' argumentative strangenesses.

\section{AcCommodating an Alternative Version}

We are approaching the end of the argument. Yet before summarizing it and discussing the implications, I wish to suggest that my interpretation, based on Detienne's thesis about Greek sacrifice, could make it possible to understand other myths better, and other versions of myths. It has been claimed that there must have been a variant of the myth - one that could at first appear to be incompatible not only with the "standard version" of the myth but also with Euripides" treatment of it, and, likewise importantly, with my interpretation of the Cretans.

It has been argued that according to this second variant of the myth, Minos did not sacrifice another bull instead of the one he had promised Poseidon. Interpreting a Roman sarcophagus (now in the Louvre and in the Villa Borghese), Carl Robert claimed that a woman carrying a basket represents Pasiphae with fruit offerings for Poseidon, and that this implies a now-lost second version of the myth, according to which Minos had refrained from sacrificing the bull on ethical and religious grounds. "Minos der Mystiker" had, Robert argued, adopted

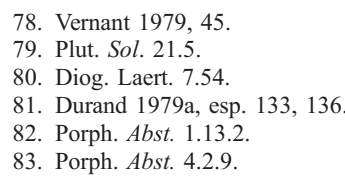


the new religion of the Zeus priests, and observing vegetarianism, he had substituted fruit for the bull and hence incited the fury of the god. ${ }^{84}$

This is reminiscent of Cain's offering, which was, unlike that of Abel's meat, rejected by God. ${ }^{85}$ But in ancient Greece there was nothing strange about offering vegetarian nourishment, such as fruit and cakes. For example, Kekrops, the legendary founding father of Athens, pleased Zeus by offering him cakes. ${ }^{86}$ And Pausanias informs us that only cakes were offered at the altar of Zeus Hypatos in the Erechtheion in Athens - that is, that no animals were sacrificed. ${ }^{87}$ And apart from such offerings and sacrifices, there were of course libations. Yet what is important in this context is that Poseidon demanded meat, that is, the bull, and Minos did not keep his promise. ${ }^{88}$

Is it likely that there was in fact a version of the myth according to which Minos omitted the sacrifice on vegetarian grounds? Wilamowitz, for one, thought that this was the case. ${ }^{89}$ And Robert's interpretation is sometimes considered in contemporary scholarship. ${ }^{90}$ The view is, however, arguably much too imaginative for its own good, and it makes fairly much out of very little, in this case a late set of images. ${ }^{91}$ Yet the possibility of Minos being a vegetarian of this kind is intriguing, not least given Pasiphae's sarcastic invitation to cannibalism. But again, even if it could be shown on the basis of other sources that such a version existed, my interpretation would be able to incorporate that variant as well. André Rivier argued that Robert's interpretation was incorrect, and that Pasiphae's accusations cannot possibly allude to the idea that Minos was an ascetic vegetarian. ${ }^{92}$ But if the meaning of Euripides' series of argumentative peculiarities is to uncover an underlying, systematic normative principle, and if he does so by showing that these deviations from the principle are symmetrical according to the principle itself, then Minos' vegetarianism and cannibalism would be quite compatible, in a curious, paradoxical way. The world of the Cretans is out of joint, and its order is disorder; it is distorted. This is not to say that the blurring of the boundary between man and animal is invariably considered a monstrous aberration in Greek - as discussed above, it is a living historial reality in the perceived community of hunter and predator. In principle and structurally, the eating of raw meat could make sense with reference to this complex of thought. Yet the Cretans would be difficult to render intelligible in that context; not so, however, in that of another political institution. We have seen that vegetarianism, cannibalism, the eating of raw meat, and omission of sacrifice subvert the cosmological hierarchy. This disorder is incarnate, embodied, in the creature in the labyrinth: bulls do not eat meat, Greeks do not eat raw meat, civilized humans do not eat human flesh.

84. Robert 1890, 15, 19-23; LIMC, Minos I, 1.

85. Genesis 4:4-7.

86. Paus. 8.2.3.

87. Paus. 1.26 .5

88. This is abundantly clear from 472e23-24; before the publication of the Berlin papyrus and this fragment, Gustav Körte supposed that Euripides had invented the Hyginus version, according to which it was Aphrodite, not Poseidon, who induced Pasiphae's frenzy; see Körte 1884, esp. 206.

89. Wilamowitz 1907, 76-77.

90. See, e.g., Dolfi 1984, 126 n. 13; D’Alfonso 2006, 64 n. 131

91. Jouan and van Looy 2001, 315 .

92. Rivier 1975, esp. 45 . 
Yet the bull-man monster, the Minotaur, is incorrect in every way: he devours raw human flesh.

If the interpretation suggested here is plausible, then Euripides expounds the norms of sacrifice. "Sacrifice" is not to be understood as functionally different from politics, morality, or religion: the slaughtering, cooking, and eating of animals is all of this. By constructing a set of argumentative aberrations, Euripides helps us discover a fundamental politico-theological principle and its implications.

\section{CONCLUSIONS AND IMPLICATIONS}

The argument is coming to an end, and it is time to lay out the implications. First, this is a new way of understanding a Euripidean riddle that earlier scholars have been unable to solve, and as such, the interpretation should shed new light on Euripides, on his relation to the political and religious practices of his city, and by extension on the political institutions and the self-understanding of the Greek poleis. Yet the implications for our understanding of Euripides' views are not obvious. He could be sarcastic vis-à-vis Orphic doctrines, or he could express sympathy for them - both these positions have been defended by earlier scholars. ${ }^{93}$ Yet the logical strangeness of the Cretans can now be understood in light of the normative principle that underlies Euripides' transformation of the myth, and the ramifications of this understanding may solve other problems in the fragments.

Second, while some scholars have argued that Greek tragedy inhabits a prelogical and anti-logical world, in which logical inconsistencies are not considered to be a problem, we have revealed that even a fragmentary drama with obvious logical peculiarities is in its own way systematic in expounding a fundamental normative principle and its implications. The notion of a "primitive mentality," Greek or otherwise, has a long history. For Lucien Lévy-Bruhl, a "pre-logical" mind was an element in this supposed primitive mentality. ${ }^{94}$ But this conception did not disappear when Lévy-Bruhl renounced the thesis for which he became famous. On the contrary, it is sometimes stated in more or less radical versions by contemporary scholars. In an influential work, Wouter Oudemans and André Lardinois argue that "the introduction of the principle of non-contradiction as the basis of the separation of consistent truth from changeable opinion" is the "fundamental event in Greek philosophy," brought about by Plato and unprecedented in Greek culture. ${ }^{95}$ The implication was that Greek tragedy inhabited a world unharmed by logic, in which inconsistent claims were $c e-$ teris paribus considered to be just as reasonable or valid as other utterances. And scholars have been most tolerant to perceived inconsistencies in Euripides, claiming that this was quite simply his style. ${ }^{96}$ This is likewise true of the other trage-

\footnotetext{
93. For the former, cf. Wilamowitz 1931-32, 1: 113; Nilsson 1935, 206; for the latter, Croiset 1915, 227, 229; Méridier 1928, 31.

94. E.g., Lévy-Bruhl 1922, 2, 14, 42, 47, 85

95. Oudemans and Lardinois 1987, 206.

96. See, e.g., Méridier 1928, 17: “des négligences plus choquantes [than Hippolytos] ne sont pas rares chez Euripide."
} 
dians, perhaps particularly Sophokles. ${ }^{97}$ Yet if even the Cretans, the most blatantly contradictory fragment of all and hence the least likely case, can be recovered as a systematic and consistent elucidation of a normative principle - consistent, that is, through its use of inconsistencies and incongruencies that serve the purpose of unveiling the implications of the principle itself - then we are well-advised to put the thesis of "pre-logical cosmologies" to rest. In short, we need to rediscover tragedy as a rationalistic and philosophical work of art.

The point is not an imperialistic one: it is not about indicating the sole way of reading Greek tragedy. Rather, the purpose is to show the possibility of reading the tragic art as systematic political thinking, operating with and interpreting normative principles, and the way in which tragedy applies these principles to political, cosmological, and moral problems. The work done in the fragments from the Cretans may look very different from, say, philosophical treatises on politics as the genre later developed, and they could seem to have a strange relationship with the insight that inconsistent statements cannot be true. Yet political philosophy can, as exemplified by Plato, operate with inconsistencies for pedagogical purposes, as a way of working out implications of the general norms that we label principles, and which govern our thinking and actions. Logical inconsistencies and argumentative incongruencies can thus serve to uncover the principles underlying ethics, sacrifice, politics, ritual, and community. The shards of the Cretans that have come down to us are thus, in their own very strange and sophisticated way, a part of the beginnings of Greek political philosophy.

Uppsala University

97. Cf., e.g., Perrotta 1935, 59-60, 299, 633; Flashar 2000, 194; Jouanna 2007, 258.

\section{LITERATURE CITED}

Austin, Colin, ed. 1968. Nova fragmenta euripidea in papyris reperta. Berlin.

Bremmer, Jan. 2008. Myth and Ritual in Greek Human Sacrifice: Lykaon, Polyxena and the Case of the Rhodian Criminal. In The Strange World of Human Sacrifice, ed. Jan Bremmer, 55-79. Leuven.

Burford, Alison. 1969. The Greek Temple Builders at Epidauros: A Social and Economic Study of Building in the Asklepian Sanctuary, during the Fourth and Early Third Centuries B.C. Toronto.

Burkert, Walter. 1977. Griechische Religion der archaischen und klassischen Epoche. Stuttgart. 1997. Homo Necans: Interpretationen altgriechischer Opferriten und Mythen. Berlin.

Burnett, Anne Pippin. 1998. Revenge in Attic and Later Tragedy. Berkeley and Los Angeles.

Cantarella, Raffaele, ed. 1963. I Cretesi. Milan.

Collard, C., and M. J. Cropp, eds. 2008. Euripides. Vol. 7, Fragments. Cambridge, Mass.

Collard, C., M. J. Cropp, and K. H. Lee, eds. 1995. Euripides: Selected Fragmentary Plays. Vol. 1. Warminster.

Cozzoli, A.-T., ed. 2001. Euripides: "Cretesi”; Introduzione, testimonianze, testo critico, traduzione e commento. Pisa.

Croiset, Maurice. 1915. Les Crétois d'Euripide. RÉG 28: 217-33.

D'Alfonso, Francesca. 2006. Euripide in Giovanni Malala. Alessandria. 
Detienne, Marcel. [1977] 1998. Dionysos mis à mort. Paris. 2007. Les dieux d'Orphée. Paris.

Detienne, Marcel, and Jesper Svenbro. 1979. Les loups au festin ou la cité impossible. In Detienne and Vernant 1979, 215-37.

Detienne, Marcel, and Jean-Pierre Vernant, eds. 1979. La cuisine du sacrifice en pays grec. Paris. Dolfi, Ezio. 1984. Su I Cretesi di Euripide: Passione e responsabilità. Prometheus 10: 121-38.

Durand, Jean-Louis. 1979a. Bêtes grecques: Propositions pour une topologie des corps à manger. In Detienne and Vernant 1979, 133-65.

. 1979b. Du rituel comme instrumental. In Detienne and Vernant 1979, 167-81.

- 1997. La mort, les morts et le reste. Systèmes de pensée an Afrique noire: Destins de meurtiers 14: 39-56.

Edmonds, Radcliffe. 2008. Mystai and Magoi, Magicians and Orphics in the Derveni Papyrus. $C P$ 103: 16-39.

Festugière, André-Jean. 1972. Les mystères de Dionysos. In Etudes de religion grecque et hellénistique, 13-63. Paris.

Flashar, Hellmut. 2000. Sophokles: Dichter im demokratischen Athen. Munich.

Fornari, Giuseppe. 1997. Labyrinthine Strategies of Sacrifice: The Cretans by Euripides. Contagion: Journal of Violence, Mimesis, and Culture 4: 163-88.

Gallistl, Bernhard. 1981. Der Zagreus-Mythos bei Euripides. WürzJbb 7: 235-52.

Giuliani, Alessandro. 1998. Perdonare Elena: Bellezza e giustizia negli intellettuali della crisi (Gorgia, Euripide, Isocrate). In Responsabilità perdono e vendetta nel mondo antico, ed. Marta Sordi, 25-46. Milan.

Harrison, J. E. 1903. Prolegomena to the Study of Greek Religion. Cambridge.

Heath, John. 2005. The Talking Greeks: Speech, Animals, and the Other in Homer, Aeschylus, and Plato. Cambridge.

Herrero de Jáuregui, Miguel. 2010. Orphism and Christianity in Late Anitiquity. Berlin.

Hodge, A. Trevor. 1960. The Woodwork of Greek Roofs. Cambridge.

Hünemörder, Christian. 2003. Zypresse. In Der neue Pauly, vol. 12.2, ed. H. Cancik and H. Schneider. Stuttgart.

Jameson, Michael. 1988. Sacrifice and Animal Husbandry in Classical Greece. In Pastoral Economies in Classical Antiquity, ed. C. R. Whittaker, 87-120, CPS Supp. 14. Cambridge.

Jiménez San Cristóbal, Ana Isabel. 2009. ¿Hubo ritos de paso cruentos en el Orfismo? Synthesis 16: 83-97.

Jouan, François, and Herman van Looy, eds. 2001. Euripides: Fragments. Vol. 8.2. Paris.

Jouanna, Jacques. 2007. Sophocle. Paris.

Kannicht, Richard, ed. 2004. Tragicorum Graecorum Fragmenta. Vol. 5, Euripides. Göttingen.

Käppel, Lutz. 1992. Paian: Studien zur Geschichte einer Gattung. Berlin.

Kern, Otto. 1916. Orphiker auf Kreta. Hermes 51: 554-67.

Klosko, George. 1984. The Refutation of Callicles in Plato's Gorgias. GaR 31: 126-39.

Körte, Gustav. 1884. Die Kreter des Euripides. In Historische und philologische Aufsätze: Festgabe an Ernst Curtius zu seinem siebenzigsten Geburtstage am zweiten September 1884 gewidmet, 197-208. Berlin.

Lévy-Bruhl, Lucien. 1922. La mentalité primitive. Paris.

Lloyd, G. E. R. 1966. Polarity and Analogy: Two Types of Argumentation in Early Greek Thought. Cambridge.

MacLeod, Leona. 2001. Dolos and Dike in Sophokles' "Elektra." Leiden.

Méridier, L. 1928. Euripide et l'Orphisme. BAssBudé 18: 15-31.

Nilsson, Martin P. 1935. Early Orphism and Kindred Religious Movements. HTR 28: 181-230.

Oudemans, Th. C. W., and A. P. M. H. Lardinois. 1987. Tragic Ambiguity: Anthropology, Philosophy and Sophocles' "Antigone." Leiden.

Perrotta, Gennaro. 1935. Sofocle. Messina. 
Reckford, Kenneth. 1974. Phaedra and Pasiphae: The Pull Backward. TAPA 104: 307-28.

Rivier, André. 1960. L'élément démonique chez Euripide jusqu'en 428. In Entretiens sur l'antiquité classique, vol. 6, Euripide, 43-72. Geneva.

1975. Euripide et Pasiphaé. In Etudes de littérature grecque, 43-60. Geneva.

Robert, Carl. 1890. Der Pasiphae-Sarkophag. Halle.

Rosivach, Vincent. 1994. The System of Public Sacrifice in Fourth-Century Athens. American Classical Studies 34. Atlanta.

Sansone, David. 2013. Euripides, Cretans frag. 472e.16-26 Kannicht. ZPE 184: 58-65.

Schmidt, Margot. 1992. Daidalos und Ikaros auf Kreta. In Kotinos: Festschrift für Erika Simon, ed. Heide Froning, Tonio Hölscher, and Harald Mielsch, 306-11. Mainz/Rhein.

Skinner, Quentin. 2002. Meaning and Understanding in the History of Ideas. In Visions of Politics, vol. 1, Regarding Method, 57-89. Cambridge.

Snell, Bruno. 2000. Die Entdeckung des Geistes: Studien zur Entstehung und Entwicklung des europäischen Denkens bei den Griechen. Göttingen.

Svenbro, Jesper. 2007. Sylosons mantel och andra grekiska myter. In Försokratikern Sapfo och andra studier $i$ antikt tänkande, 138-50. Gothenburg.

Tralau, Johan. 2015. Monstret i mig: Myter om gränser och vilddjur. Stockholm.

. 2016. A Portrait of the Warrior as a Beast: Hunter, Man, and Animal in Sophocles' Trachiniae and Schwarzenegger's Predator. In Transforming Warriors: The Ritual Organization of Military Force, ed. Peter Haldén and Peter Jackson, 19-35. London.

Turcan, Robert. 1986. Bacchoi ou bacchants? De la dissidence des vivants à la ségrégation des morts. In L'association dionysiaque dans les sociétés anciennes, ed. Olivier de Cazanove, 227-46. Rome.

Vernant, Jean-Pierre. 1979. A la table des hommes: Mythe de fondation du sacrifice chez Hésiode. In Detienne and Vernant 1979, 37-132.

Vidal-Naquet, Pierre. 2001. Chasse et sacrifice dans 1'Orestie d'Eschyle. In Mythe et tragédie en Grèce ancienne, ed. Jean-Pierre Vernant and Pierre Vidal-Naquet, 1: 133-58. Paris.

Webster, T. B. L. 1967. The Tragedies of Euripides. London.

Wilamowitz-Moellendorf, Ulrich von, ed. 1907. Berliner Klassikertexte. Vol. 5. Berlin.

_. 1931-32. Der Glaube der Hellenen. Vols. 1-2. Berlin. 